HUMANITAS ISayı - Number: 3

Bahar / Spring, Tekirdağ, 2014

\title{
VICTORIAN CRITICS AND METACRITICS: ARNOLD, PATER, RUSKIN AND THE INDEPENDENCE OF LITERARY CRITICISM
}

\author{
Petru GOLBAN ${ }^{1}$
}

Öz: Viktorya dönemi eleştirmenleri, İngiliz eleştiri kuramının 20 yüzyıldaki bilimsel ve yöntembilimsel oluşumundan önce, kuramın gelişimine yönelik son büyük adımı atmışlardır. Viktorya dönemi eleştirisi ayrıca çağdaş edebiyat kuramı ve eleştirisine geçişi ve bu geçişin modern kuram ve eleştirisinde son buluşunu temsil eder. 19. yüzyılda bir dönem boyunca farklı sanatsal ve yazınsal akımların bir arada bulunması eleştirinin yazınsal süreçten ayrılmasına yol açmıştır. Eleştirinin yazınsal uygulamalardan ayrılması yazınsal türlerin çeşitliliğinden de kaynaklanmaktadır. Fakat öncelikle eleştirinin yazından bağımsızlığı, yaratıcı ve eleştirel yazının eleştirmenlerin bilimle yazınsal eleştiriyi birlikte özümsedikleri felsefi düşüncelerdeki, toplumsal kuramlardaki ve bilimsel ilerlemelerdeki çeşitlilik ve karmaşıklığın etkisi altında kalmasından doğar. Eleştirinin yazından bağımsızlığa doğru ilerleyişi türsel olarak oluşumuyla ve kendi içindeki çeşitlilikle bağlantılıdır. Viktorya dönemi eleştirisini sınıflandırmak neredeyse olanaksız olsa da, yaşamöyküsel, toplumbilimsel, tarihsel, olgucu, gerçekçi, doğalcı, izlenimci, güzelduyusal, törel, insancıl ve benzer eleştiri kuramlarını da kapsayan romantik kuram, etkisini hala sürdürmektedir. Viktorya dönemi eleştirel sistemlerdeki farklılık Walter Pater, Matthew Arnold ve Henry James gibi yazar-eleştirmen ve John Ruskin gibi usta eleştirmenlere ait farklı eleştirel düşüncelerin varlığının bir sonucudur. $\mathrm{Bu}$ eleştirmenler, meta eleştirmenlerinin eleştiri üzerine eleştirel düşünceler üretmesi gibi, sanata ve/veya yazına odaklanırlar. Bu yazının amacı, onların eleştirel konumlarının önemini ve Viktorya dönemi eleştirisinin durumunu ortaya koyan düşünceleri incelemektir.

Anahtar Sözcükler: Viktorya Dönemi, Yazın Yaklaşımları, Yazınsal Eleştiri, Yazın Kuramı, Yazınsal Tarih, Metaeleştiri, Eleştirmen, YazarEleştirmen.

\section{Introduction and Terminological Explanation}

During its movement through history to the present day, literature has attracted much attention from three general perspectives which represent three major approaches to literature. They are commonly designated as critical, theoretical, and historical; in other words, literary criticism, literary theory (the theory of

\footnotetext{
${ }^{1}$ Doç. Dr., Namık Kemal Üniversitesi, Fen-Edebiyat Fakültesi, İngiliz Dili ve Edebiyatı Bölümü. pgolban@nku.edu.tr
} 
literature), and literary history (the history of literature). They are parts of a single science, the science of literature, aiming to explain and evaluate the creative writing. They have as their object of study an art, namely the art of literature, or, in other words, the work of literary art, which is the text, and all the elements that build up and condition the work of literature. In particular, apart from the text as the main element of the literary system, they focus on author, reader, language, society, related texts, performer, and others.

Literary criticism, literary theory and literary history are also parts of a single cognitive system that assists the pragmatic function: to form and facilitate a particular type of communication which involves the producer of literature and its receiver.

Literary criticism, literary theory and literary history are interconnected and interdependent, having obvious points of identification and separation. And despite the huge debates over their functions, importance and even necessity, these approaches represent three distinct scientific disciplines having their own definitions, characteristics, terminology, objects of study, and methodologies.

The standard dictionary definition regards literary history as the diachronic approach to literature which focuses on literary periods, movements, trends, doctrines, and writing practice (authors and works), all that represents the "objective facts of literary history" (Jauss, 1982, p. 51). Literary criticism is the study, analysis, investigation, approach to particular literary texts on both thematic and structural levels. Criticism interprets the text, discloses its meaning, and mediates between the text and the reader. In the process of critical interpretation, the complete meaning emerges out of the investigation of both content and form, which are organically fused, since it is impossible to separate "what" is said in a literary work, or "what" is the text about, from "how" it is said, or the "way" in which the text is written. Literary theory looks at the nature of literature itself; it develops and offers terms, concepts, rules, criteria, categories, general strategies, methodologies and principles of research of the literary phenomena, including the text and other elements of the literary system. Theorizing within the field of literary studies attempts to answer the question "What is literature?", and literary theory, also referred to as "poetics", is "the systemic account of the nature of literature and of the methods for analysing it" (Culler, 2009, p. 1).

If the first, historical, approach embarks on a diachronic perspective in literary studies and investigates the development of national and world literature, the second is considered synchronic, and the third one is referred to as universal.

In matters of subjectivism and objectivism, literary history and, especially, literary theory are designated as sciences, requiring normative and methodological objectivism. Literary criticism is also required to be objective and to concentrate solely on text, not context. Literary criticism, however, allows subjectivism to intermingle with objective reasoning, art with science, fusing in one discourse the personal responses to literature and the scientific research, but what the critical discourse requires most is the accurate balance 
between the subjective and objective components. The predominance of one element or another in the critical act makes a certain type of criticism to be practical, or impressionistic, or theoretical, or analytic, or academic, and, according to various methods and principles, the critics are also categorized as formal, historical, moral, analytical, descriptive, affective, psychological, and soon.

The interrelationship and interdependence of literary theory, literary criticism and literary history form a permanent circular movement from the historically placed literary practice to literary criticism, from literary criticism to literary theory and from literary theory back to criticism.

The text - either produced recently or representing an earlier period in literary history - is subject to literary criticism whose concluding reflections (the necessary outcome of literary criticism), if generally accepted and proved valid in connection to other thematically and structurally similar literary texts, emerge into the domain of literary theory, become its general principles of approach to literature and are applicable to the study of other particular texts and to the understanding of literature in general.

Literary criticism uses theory in practical matters of research whenever the study of particular literary works is required, adding to the objective theory the critic's individual response to the text. The expected result is, on one hand, the development of new or alternative theoretical perspectives, and, on the other hand, the change, promotion, discouragement, revival or in some other ways the influence upon the literary practice of its own historical period, and the influence upon the literary attitude of the reading audience concerning the contemporary and past literary tradition.

Literary theory is fed and supported by the outcome of the practical action of criticism, but it often also "develops out of the application of a more general theory (of art, culture, language and linguistics, aesthetics, politics, history, psychology, economics, gender, and so on) to literary works in the interests of a specific critical aim", meaning that theory "grows out of this experimentation with concepts, terms, and paradigms taken from other spheres of intellectual activity" (Castle, 2007, p. 9).

Literary criticism is thus not to be regarded as just the analysis or evaluation of particular literary works, but also as the formulation of general principles of approach to such works. Co-existing in the field of literary studies with literary history and literary theory, literary criticism combines the theoretical/scientific and practical levels of literary analysis. Criticism as science follows and applies the general principles and methods of research from literary theory, but it also reveals an artistic/creative aspect when the critic personalizes the discourse by his/her own opinions.

Our post-modernity and post-modernism having proclaimed the death of history and historicity and having argued about the uselessness of theory, it has come the turn of literary criticism to be viewed as a metatext, a second degree text, a valueless imitation of the original literary text emerging in the process of 
reading. Northrop Frye speaks about the popular among artists conception of the critic as a parasite and consequently literary criticism as a

parasite form of literary expression, an art based on pre-existing art, a second hand imitation of creative power. On this theory critics are intellectuals who have a taste for art but lack both the power to produce it and the money to patronize it, and thus form a class of cultural middlemen, distributing culture to society at a profit to themselves while exploiting the artist and increasing the strain on his public. (Frye, 1990, p. 3)

However, if there are debates whether the average reader needs or not any help from criticism, concerning professional readers, academics and students, criticism has definitely acquired a solid position in the field of literary education. Moreover, literary criticism has proved to be an important and necessary domain for centuries, providing, among other things, the establishment of literary traditions, advancement of literary practice, expression of literary value, and mediation between art and its audience. The question is not about the necessity of criticism but about the professional validity of the critics.

The interconnected terms "criticism", "critic", "criticise", "critical", and "critique" entered English language at the beginning of the modern period, largely around 1600. The etymology of all these words starts in ancient Greek, namely from Greek krites ("judge, a person offering reasoned judgement or analysis") and its derivation kritikos ("skilled in making judgement"), as well as krinein ("to decide, to separate") and krinô ("I judge", or "to separate and distinguish in order to be able to judge"), which is also the root for the word "crisis". From Greek they passed into Latin, then French and finally English. The term "critic", for instance, having in 1580s the meaning of "the one who passes judgement" and from c.1600 on that of "censurer, the one who judges quality of books", entered at that time English from medieval French critique, which comes from Latin criticus ("judge, critic of literature") which derives originally from Greek. "Criticism", from "critic" and "-ism", meant around 1600 "the act of criticising" and from 1670s on "art of estimating literary works".

The person criticising literary texts is called "critic" and the critic who analyses and evaluates literary criticism is called "metacritic". The critic who is also the creator of imaginative writing is called "creative critic" or "writer-critic" and the metacritic producing literary works is called "creative metacritic". Nowadays, the distinction is usually made between three types of critic, namely "academic", "freelance" and "writer-critic". The first type is almost nonexisting before the twentieth century but dominates the contemporary field of literary theory and criticism from the height of universities and similar institutions. The second emerges at the end of the seventeenth century with the rise of journalism and produces criticism written in the form of reviews and magazine articles. The third kind is represented by the producers of two types of writing, creative and critical, the latter, in their view, itself being a form of literature. In David Lodge's words, the writer-critic is 
the creative writer whose criticism is mainly a by-product of his creative work. $\mathrm{He}$ is less disinterested than the academic, more concerned to work out in the practice of criticism the aesthetic principles of his own art, and to create a climate of taste and opinion favourable to the reception of that art. (Lodge, 1971, p. 247)

David Lodge, for instance, is the author of both imaginative and critical works, and he often combines both creative and critical discourses in one text, as in his trilogy of campus novels; he is thus both writer and critic, novelist and theoretician of literature, as well as metacritic. Actually, the most important critics before the twentieth century were writer-critics and writer-metacritics, as to mention just Philip Sidney, John Dryden, Alexander Pope, Samuel Johnson, Henry Fielding, William Wordsworth, Samuel Taylor Coleridge, Percy Bysshe Shelley, Thomas Carlyle, Matthew Arnold, Walter Pater, Oscar Wilde, Henry James, and others.

\section{The Condition of British Literary Criticism for the Periods Preceding Victorian Age}

Nowadays, literary criticism and literary theory are two distinct but interrelated and interdependent disciplines, and they are often considered as one field under the label of "literary theory and criticism". The contemporary domain of literary theory and criticism represents a scientific, objective and methodological discourse consisting of a number of trends and schools which focus on particular elements of the literary system. Thus, the "author" is the matter of concern of literary scholarship and biography; "text" is studied by Formalism, linguistics, linguistic criticism, and stylistics; "performer" by acting theory; "reader" by phenomenology, hermeneutics, reception theory, reader-oriented and reader-response theory, as well as by psychoanalysis, feminism, and poststructuralism; "society" by Marxist theories, cultural materialism, New Historicism, and feminism; "texts" by structuralism, poststructuralism, and deconstruction; and corresponding to "language" are the theories of linguistics and stylistics. Concerning intertextualism, themes, motives, influence, reception, and in general the different relations between the literary works, the initiative is that of comparative literature. The particular elements of the literary system and literature on the whole are also the matters of critical and theoretical concern of rhetoric, semiotics, Bakhtinian criticism, archetypal and myth criticism, folklore studies, ethnic literary studies, racial studies, colonial, postcolonial and transnational studies, cultural studies, environmentalism and ecocriticism, and other contemporary trends and schools in humanities and in literary theory and criticism. These theories, trends and schools represent the twentieth century and the contemporary scientific and methodological literary theory and criticism which emerged at the beginning of the last century with the rise of the formal approach to literature consisting of Russian Formalism, Anglo-American New Criticism, and later French Structuralism.

Until the rise of the formal critical theories at the dawn of the last century, literary criticism had a long history of development with its origins in ancient Greece and Rome. It continues in the Middle Ages having a rather diminished 
status. The first modern methodological and analytical attempts at criticism based on the ancient revived tradition occurred at the beginning of the modern period in the Renaissance both in Britain and in Europe in general.

Throughout the centuries criticism developed within the context of the literary practice, but gradually came to diversify its provenance, form, and category as to separate from the realm of literature in the nineteenth century and finally to flourish as an independent and scientific domain in the twentieth century and at the present time which represent undoubtedly an age of criticism.

Throughout its history criticism existed in a variety of forms, including dialogues, verse, essays, letters, prefaces, treaties, books.

Throughout its history criticism belonged mainly to the domains of literature and philosophy. Criticism has been continuously influenced by the literary process and has influenced in its turn this process. Criticism has been also continuously influenced by the new developments in thought as well as in natural and social sciences, art, culture, ideology, psychology, linguistics. As such, criticism has developed an impressive typology to which twentieth century and the present day added a huge diversity of critical trends and schools.

Throughout its history criticism has concerned first philosophers and later, to a much greater extent, artist-critics and writer-critics, especially poet-critics, as well as scholars from different fields (rhetoric, logic, mathematics, physics, sociology, psychology, linguistics, etc.), and finally reviewers, university academics, and just professional critics and theoreticians of literature.

All the way through the periods, including twentieth century, the field of literary theory and criticism reveals a threefold perspective of development. First, one may argue that the development of literary criticism is dependent on literary genres and movements that are dominant in different periods. This is the case of literary criticism especially for the periods until twentieth century. For instance, neoclassical criticism, or the biographical method in criticism as an effect of Romanticism.

Second, which is mainly the case of literary scholarship in nineteenth and twentieth centuries, trends and schools in literary criticism are related to or rather determined by the new developments in science, philosophy, and society. For instance, "There is an unmistakable influence of Freudian psychology in psychologically-oriented literary criticism", or "Marxist literary criticism has been intertwined with particular political and sociological views", or "Russian Formalism is not only indebted to futurism, but also to new developments in linguistics" (Fokkema and Ibsch, 1995, p. 1-2).

Third, although most of the trends in literary criticism are related either to the trends in creative literature or to particular developments in scholarship and society, there are critical trends, especially in the twentieth century and contemporary period, that emerge from within the interpretative perspectives of the discipline of literary theory and criticism itself (for instance, narratology developed from within Structuralism). 
According to M. H. Abrams in his celebrated The Mirror and the Lamp: Romantic Theory and the Critical Tradition (1953), when viewed diachronically, the development of art and art criticism in the Western world reveals that from Antiquity through the most of the eighteenth century the mimetic and pragmatic theories on art and literature were dominant, whereas the expressive theory of authorship emerged as the most characteristic of the Romantic attitudes towards art, and also dominant in the nineteenth century and later in the twentieth century was the objective theory on art, based on the idea of art for its own sake, art per se, the work being viewed as a separate entity, complex enough in its range of symbols and imagery, and its patterns of structure and form, to be a matter of critical concern in itself. However, the present diversity of approaches to art keeps the contemporary critic aware of all the four major theories in his/her endeavour to evaluate art.

A closer look at the rise of the critical tradition in Britain reveals a process of development during certain periods or stages generally corresponding to periods and movements in English art and literature. British literary criticism, in particular, reveals some concerns with literature in the medieval period, but its actual beginnings are found in the Renaissance, and its development and consolidation occurred during the subsequent periods of Restoration, neoclassicism, Romanticism, and the Victorian age, as to establish itself in the twentieth century as a scientific discipline.

The discussion on the foundations of modern English literary criticism starts with Sir Philip Sidney and his The Defence of Poesie to understand the condition of English criticism in its first phase, which is the Renaissance. John Dryden and his Of Dramatic Poesie, An Essay show the condition of English criticism in Restoration. The eighteenth century criticism which is dependent on neoclassical principles can be better seen in Alexander Pope's An Essay on Criticism and An Essay on Man, and the rise of the English novel in the same century receives a critical expression in Henry Fielding's Preface to Joseph Andrews. The Romantic period in the history of English literary criticism would be better revealed by focusing on William Wordsworth's Preface to Lyrical Ballads, Samuel Taylor Coleridge's Biographia Literaria, and Percy Bysshe Shelley's A Defence of Poetry. The condition of literary criticism in the Victorian age, the last before the twentieth century stage in the development of criticism, might be better disclosed by the assessment of Matthew Arnold's various studies, among which The Study of Poetry, John Ruskin's Modern Painters, Walter Pater's Studies in the History of the Renaissance, or Henry James's The Art of Fiction.

With a few exceptions in Victorian Age, literary history remembers them as authors of imaginative literature rather than critics, excelling in different periods and different genres, or even as founders of new genres and as promoters of various literary trends and movements. But their critical status in British literary history should not be neglected, even if they would often deviate from the main purpose of criticism to focus in order to evaluate and understand particular literary works. Sidney, for instance, defends poetry against Puritan accusations. 
Dryden prescribes ways of writing. Fielding introduces a new genre and defends in his critical work the literary value of the novel as a new literary form in English literature, in general, and of the comic novel, in particular. Wordsworth rejects a type of poetry and introduces a new one and his critical endeavour, together with that of Coleridge, helps the implementation into the contemporary neoclassicism-saturated cultural mentality of a whole new literary tradition, that of Romanticism, and defends its literary validity. Likewise, Pater develops and promotes the theoretical complexity of the late Victorian avant-garde thinking.

During the periods before the twentieth century, criticism is moral, humanistic, descriptive and biographical, depending on the perspective of approach.

But above all it is (1) dependent on the cultural background to which it belongs, expressing the ideas and principles of the movement or cultural doctrine which is dominant in a certain period. Criticism is also (2) prescriptive by explaining, giving rules and showing the direction for literary production. Criticism is also highly (3) subjective, because the critics are also writers who would overevaluate and defend their own work, exaggerate or diminish the value of the work because of the critic's personal responses to the text, or some historical context, and because criticism on the whole lacks the scientific, methodological, and objective rigour. Finally, until the twentieth century, criticism is also (4) defensive, and the defensive assessment of literature implies the concern to vindicate imagination and the freedom of artistic expression - where the most common way "of achieving this vindication was to differentiate sharply between imaginative literature (or poetry, in Sidney's sense) and all other forms of discourse" (Daiches, 1981, p. 6) - or to show the superiority of imaginative literature above all other forms of writing, or to prove the literary validity of the type of literature to which the writer-critic belongs against another type of literature or any accusation or attack on his literature.

"Dependent", "prescriptive", "subjective" and "defensive" may then be considered as "points of view" of the writer-critics, which, like in imaginative literature, in critical works stand for the position and attitude of the author from which he/she perceives and evaluates literature and communicates his/her vision on it in a relationship involving the author of literary texts (including the critic as such an author) and the reader.

Criticism is thus conceived as part of the literary world with the function to defend, prescribe, correct and serve literature. Criticism is "a part of the creative process", but this "cooperative vision will eventually vanish as criticism develops into a discipline in its own right" (Day, 2008, p. 134).

Romantic criticism, like the criticism of the previous periods, and in some respects even to a greater degree, remains subjective and combative, normative and prescriptive, and dependent on and representative of its literary tradition. But it becomes more scientific as it starts to develop theory (for example, Coleridge's theory of poetic imagination) and new critical concerns (the expressive theory of authorship focused on the poet and all related to him aspects involved in poetic creation, such as imagination, inspiration, 
sensibility), and to search and establish methodology (Coleridge who applied the philosophical method to the discussion of poetry).

In the rest of the nineteenth century, after Romanticism, that is in the second half of the century, these characteristics of criticism diminish and some become extinct, opening the way to the rise, in the twentieth century, of the first objective and scientific approach to literature, which is the formal approach consisting of Russian Formalism, New Criticism, the only "native", AngloAmerican approach, and, later in the century, French Structuralism.

\section{Victorian Criticism Showing the Separation of Critical Discourse from Literary Practice}

In short, the contemporary critical theories on literature represent a science, systematic and methodological, and so it established itself at the beginning of the twentieth century having the formal approach to literature as the first in the line. Until then, criticism was subjective, prescriptive, defensive and the whole dependent on literary practice, literary doctrine, or literary movement in general.

The separation of criticism from literature takes place in the nineteenth century in the aftermath of Romanticism, in Britain in Victorian period, which marks the transition from the subjective, prescriptive, defensive and dependent criticism to the twentieth century modern, independent, objective, scientific, and methodological critical theory with its own trends and schools having specific objects, aims, principles, and methods of literary research.

Among the nineteenth century aspects leading to literary criticism breaking away from the field of literature and to the rise and institutionalization of literary theory and criticism as an independent and scientific domain, the following are the most important ones:

1. Victorian criticism develops and expands its own typology - impressionistic, realistic, aesthetic, historical, moral-humanistic, biographical, sociological, and others - which is no longer an exponent or representative of certain literary traditions.

First and foremost, criticism develops and organizes its own typology under the influence of the contemporary developments in art, philosophy, natural sciences and social theories. In other words, the diversification of criticism relies on the emergence of the massive variety of principles and points of view in different domains of social and natural sciences - philosophy, psychology, sociology, biology, physics, medicine, and others - and the critics attempt to assimilate science to literary criticism. Coleridge has already showed the way by taking philosophy and its method as a means of developing the theoretical commentary on literature. Actually, the Romantic critical theory is still a very strong presence influencing the literary activity and especially the critical thinking of the Victorians. But, as a result of the influence of various domains and the widespread faith in social, historical, and scientific progress, many specialised approaches to literature emerge, such as historical criticism and related social or sociological criticism, biographical criticism, moral criticism, humanistic 
criticism, realistic criticism, naturalistic criticism, psychological and later psychoanalytic and archetypal types of criticism, as well as impressionistic approach, aesthetic theories, and others.

Among the developments in natural and social sciences providing theoretical, methodical and methodological basis to criticism, the most important are the principles of democracy, feminism, socialism, Darwin's evolution, Comte's view of society, Marx's view of history, Taine's view of literature, Ruskin's and Pater's views of art, and Freud's view of human psyche. All these theoreticians and many others elaborated hypotheses in their own fields of expertise, which are seemingly beyond the domain of literature, but which influenced both the literary practice and literary criticism in the nineteenth and twentieth centuries. Among the major nineteenth century philosophers and scientists whose work determined literary criticism to become a separate professional and scientific field of expertise having its own specialized typology, mention should be made of the following:

- Hippolyte Taine (1828-1893) is interested in society as the cause of literature and literature as the product of society. He considers literature to be the product of la race, le milieu et le moment, in History of English Literature (1864), and, together with Marx's and Comte's theories of society, Taine's opinions on literature shape a new model of literary criticism combining historical with sociological approach to literary production. By subordinating literature to sociology, Taine is one of the founders of the sociology of literature, elaborating on the concept of "determinism" and recommending the study of literature in the direction of disclosing its representation of individual as a social being and of constructing from literary texts, which are also literary documents, the moral and social history of mankind.

- Auguste Comte (1789-1857) also focuses on society as the cause of literature and literature as the product of society and influenced the realistic fiction and the sociological and historical criticism of the period. Comte's six-volume Cours de philosophie positive (1830-1842) made possible the appearance of the science of sociology, the term which he also invented. The work expresses "Positivism" as a philosophy and its scientific attitude towards social behaviour, the cause-and-effect relationship in economics, religion, culture, and other areas of human existence, and which explains the human conduct. In his work, Comte traces the famous "law of three stages", or theoretical conditions, stating that knowledge begins in theological or fictitious form, passes to the metaphysical or abstract form, and finally becomes positive or scientific. Developing one of the first theories of the "social evolutionism", Comte saw three phases in the development of human society, claiming that Europe was in the last of the three stages, "scientific" or "positive", in which man embarks on scientific research and scientific explanation of phenomena based on observation, experiment, and comparison. The scientific method is a means of positive affirmation of different theories which would offer the only authentic knowledge, which is the scientific one. 
- In France, influenced by Comte, Honore de Balzac (1799-1850), in the famous Preface to the La Comedie humaine (1842), claims that the reform of the society is useless if the spirit of its citizens is not formed and if they do not acquire new understandings that correspond to the scientific progress.

- Likewise, the famous essay Experimental Novel (1879), written by Emile Zola (1840-1902), shows the influence on literature exerted by the contemporary naturalistic philosophy and science. Like a doctor studying the organism, the novelist is a scientist not only observing but also objectively experimenting to better understand the human intellectual and emotional life and the social background which together with the biological heritage shape the character.

- Contrary to such history, society, naturalism and realism related opinions are the principles of aestheticism, Parnassians, symbolism, decadence, impressionism, and the entire spectrum of the late nineteenth century artistic avant-garde trends. The major emphasis is on the idea that art must be autonomous, which has its starting point in the 1830s with the French writer, painter, and critic Théophile Gautier (1811-1872) proclaiming the doctrine of l'art pour l'art ("art for art's sake"). With Gautier claiming that art has no utility and Poe theorizing the "poem per se", the history of criticism encounters the objective theory of art and literature, adding it to the expressive theory of authorship produced earlier by the Romantics.

- The main principles of such a theory were developed by Aestheticism, or the "art for art's sake" doctrine, an important movement in the second half of the nineteenth century, dominated in Britain by Walter Pater and Oscar Wilde. According to Aestheticism, art is autonomous, self-sufficient and serves no other purpose (moral, didactic, political, or propagandist) than the pursuit of beauty, and should accordingly be judged only by aesthetic criteria. The main theoretician of Aestheticism in England, Walter Horatio Pater (1839-1894) actually introduced the ideas of French aestheticism into Victorian England and coined the phrase "art for art's sake" in English arguing that art is self-sufficient and quite useless. Pater's most famous and influential book is Studies in the History of the Renaissance (1873) which sets the impressionistic criticism as a new trend in art criticism and focuses on the effects of a work of art on the viewer.

- Another Victorian critic dealing with art and beauty, and rejecting the dogmatic principles of his period, was John Ruskin (1819-1900) in the five volumes of Modern Painters (1834-1860).

- The most important and influential critical voice in Victorian period was that of Matthew Arnold (1822-1888), the founder of a new school of criticism called "new humanism", or humanistic, and also referred to as "moral criticism". Arnold argues about the superior status and role of poetry in society, which would come to replace philosophy and religion, and even become a part of the scientific research, and considers criticism to focus on the effects of literature on society. According to him, the major concern of criticism must be the work's effects on the emotional and moral health of the receiver, in particular, and of 
the nation, in general. His main critical studies include the Preface to the volume of Poems of 1853, The Function of Criticism at the Present Time, and The Study of Poetry.

- John Stuart Mill (1806-1873) provides a similar high estimation of poetry and its consideration as superior to prose and other forms of writing. Mill's most famous work is the essay On Liberty (1859), which shows his support for the Reform Bills, advocacy of democracy and individual freedom, and of liberty of citizens and mutual tolerance of the society members.

- Another key figure in the development of British literary criticism was Thomas Carlyle (1795-1881), who influenced the literary activity of, among others, Charles Dickens, Elizabeth Gaskell, Alfred Tennyson, William Morris, and John Ruskin. Carlyle sometimes called "the last product of the Scottish Enlightenment" and sometimes as representing the aftermath of Romanticism, emerged from within the intellectual background of the Edinburgh Review.

- Prose fiction was the dominant genre and the realistic novel was its main type. The main literary voices of the period - Charles Dickens, William Makepeace Thackeray, Charlotte Brontë, George Eliot, and Thomas Hardy - were prosewriters and exponents of realism. George Eliot and George Henry Lewes in their essays proved to be among the critics who defended realism as a moral responsibility of the novelist and focused primarily on the thematic level of the fictional text.

- Concerning the form of the novel, in Britain, it was not until the end of the nineteenth century that serious critical theories of novel, in general, and in particular, of the narrative specificity appeared, which was primarily due to Henry James (1843-1916) in The Art of Fiction (1884) which focuses primarily on the narrative point of view.

- Mary Wollstonecraft (1759-1797) with her best known A Vindication of the Rights of Women (1792) is the origin of the feminist criticism which analyses and challenges the established literary canon - that a male-dominated society stereotypes women into images of physical and moral inferiority - and develops approaches to literary works from a female point of view, developing a model of literary criticism based on a female consciousness ("gynocriticism").

- The naturalist Charles Robert Darwin (1809-1882) in On the Origin of Species (1859) exposed the scientific theory of evolution and natural selection and was applied to the discussion of man, socio-economic milieu, culture, art, and literature.

- Karl Heinrich Marx (1818-1883) produced Marxist, or materialistic, dialectics and his theories force discussions on the ways in which literature is a product of the society and the ways in which literature reflects the social and economic development of the society from which it emerges.

- Another influential philosopher of the period is Friedrich Nietzsche (18441900), whose work, highly methodological though not systematic, covers a great number of concerns ranging from the function of language and subjectivism in human perception and search for truth to theories on myth. Most 
influential writings are Thus Spoke Zarathustra and The Birth of Tragedy (1872).

- Sigmund Freud (1856-1939) developed a structural model of the psyche and the theory of the $i d$ (unconscious) in an attempt to provide the explanation of the psychological phenomenon with a scientific method, his theory having its impact not as much as on the nineteenth century as on the twentieth century, given that in 1900 he published Interpretation of Dreams, and, in 1901, The Psychopathology of Everyday Life, and establishing and influencing the psychoanalytic criticism.

- Carl Jung (1875-1961) develops new ideas on memory, personal unconscious, collective unconscious and archetypes, which diverge from those of Freud but which are also of great importance and influence on mythological and archetypal criticism, and his primary contribution to these approaches is the theory of archetypes and racial memory.

2. Victorian criticism rejects the characteristics of the earlier criticism, namely subjective, defensive, prescriptive, defensive, normative, and literaturedependent features.

3. Criticism assumes new purposes - such as to find in literature what is the best, the most valuable and moral, and help reader with apprehending all that, as for Matthew Arnold - and becomes didactic and reader-oriented.

4. The growth and diversification of literature resulted in the growth and diversification of criticism as well: Romantic literature breaks the linearity of literary development and determines the literary complexity and diversity consisting of a number of trends and movements that co-exist during the same period as innovation (symbolism, aestheticism, decadence and the whole nineteenth century avant-garde) and tradition (realism);

5. The separation of criticism from literary practice is also a result of the diversity of literary genres and forms. Poetry is romantic, post-romantic, escapist, objective, subjective, idyllic, psychological, and pre-Raphaelite. Towering over the entire period is prose fiction, and the novel also displays complex taxonomy: realistic, historical, Gothic, psychological, colonial, detective, romance, and so on.

6. The increase in the number of literary biographers, among whom Morley, Trollope, Stephen, Saintsbury, and others who are indebted to the highly popular in the nineteenth century biographical method in literary criticism developed by Sainte-Beuve.

7. The consolidation of the periodical criticism and the flourishing of periodical writing - as to mention just The Edinburgh Review, Athenaeum, Examiner, Quarterly Review, Blackwood's Magazine, London Magazine, London Review, Fraser's Magazine, The Germ, All the Year Round, The Saturday Review of Politics, Literature, Science, and Art - as well as an increase in the number of reviewers, among whom Macaulay, Lewes, Martineau, Hutton, and again Stephen, who wrote essays in periodicals on contemporary literary production, especially on Dickens's and Eliot's novels. The number of periodicals increased 
and the writing experience turned into a "business", where many authors lived exclusively by the pen.

8. Apart from the reviews and essays in periodicals, the Victorian literary criticism strengthened its status also as a result of the expansion and accessibility of elementary and higher education and literature becoming a university discipline. The establishment of English literature as a university course in England was a late phenomenon. It happened at University College London in 1828, whereas at Oxford only in 1893 and at Cambridge in 1911. The reason was, on the one hand, the monopoly of the Church of England over the two universities, Oxford and Cambridge, with their subjects in classics, divinity and mathematics, and, on the other hand, the conservative forces that since the Middle Ages allowed no change in subjects, religion, and gender. The implementation of English studies in universities culminated with the foundation of the Cambridge English in 1911, which led in its turn to the great 1920s when the academics I. A. Richards, William Empson and F. R. Leavis produced new and truly scientific critical theories and methods, probably the most influential ones in the twentieth century Anglo-American criticism.

9. Thus, a major change took place about the status of the critic that was on the way of becoming professional, since literary criticism started to be produced less by writers than by academics (usually from university chairs for study of literature, like editing of texts and providing scholarly, historical and biographical research) and journalist-critics (of different periodicals, producing informative essays and reviews).

10. Finally, the establishment of literary criticism as a separate domain is also a result of industrialization and consumerism, including the expanding publishing and printing industry, increasing demand for reading material, increasing sale of books, and development of public library system. The book trade provided financial input to the flourishing of the novel writing and consequently, the reading audience exercised its influence by expanding readership due to the spread of literacy, increase in literary taste, and the demand for entertainment.

\section{Practical Argumentation}

Criticism acquiring independence from the literary discourse, meaning the separation of criticism from literature, that is the transition of criticism from being literature depended to becoming a science, can be better seen from within the critical text containing metacriticism and thus offering a direct argumentative insight into the condition of Victorian critical theory.

From Matthew Arnold's The Study of Poetry:

We should conceive of poetry worthily, and more highly than it has been the custom to conceive of it. We should conceive of it as capable of higher uses, and called to higher destinies, than those which in general men have assigned to it hitherto. More and more mankind will discover that we have to turn to poetry to interpret life for us, to console us, to sustain us. Without poetry, our science will appear incomplete; and most of what now passes with us for religion and philosophy will be replaced by poetry. Science, I say, will appear incomplete without it. (...) 
The best poetry is what we want; the best poetry will be found to have a power of forming, sustaining, and delighting us, as nothing else can. A clearer, deeper sense of the best in poetry, and of the strength and joy to be drawn from it, is the most precious benefit which we can gather from a poetical collection such as the present. (...)

Yes; constantly in reading poetry, a sense for the best, the really excellent, and of the strength and joy to be drawn from it, should be present in our minds and should govern our estimate of what we read. But this real estimate, the only true one, is liable to be superseded, if we are not watchful, by two other kinds of estimate, the historic estimate and the personal estimate, both of which are fallacious. A poet or a poem may count to us historically, they may count to us on grounds personal to ourselves, and they may count to us really. They may count to us historically. The course of development of a nation's language, thought, and poetry, is profoundly interesting; and by regarding a poet's work as a stage in this course of development we may easily bring ourselves to make it of more importance as poetry than in itself it really is, we may come to use a language of quite exaggerated praise in criticising it; in short, to overrate it. So arises in our poetic judgments the fallacy caused by the estimate which we may call historic. Then, again, a poet or poem may count to us on grounds personal to ourselves. Our personal affinities, likings and circumstances, have great power to sway our estimate of this or that poet's work, and to make us attach more importance to it as poetry than in itself it really possesses, because to us it is, or has been, of high importance. Here also we overrate the object of our interest, and apply to it a language of praise which is quite exaggerated. And thus we get the source of a second fallacy in our poetic judgments - the fallacy caused by an estimate which we may call personal.

From John Ruskin's Modern Painters:

The Imaginative artist owns no laws. He defies all restraint, and cuts down all hedges. There is nothing within the limits of natural possibility that he dares not do, or that he allows the necessity of doing. The laws of nature he knows; these are to him no restraint. They are his own nature. All other laws or limits he sets at utter defiance; his journey is over an untrodden and pathless plain. (...)

And now we find what noble sympathy and unity there are between the Imaginative and Theoretic faculties. Both agree in this, that they reject nothing, and are thankful for all: but the Theoretic faculty takes out of everything that which is beautiful, while the Imaginative faculty takes hold of the very imperfections which the Theoretic rejects; and, by means of these angles and roughness, it joints and bolts the separate stones into a mighty temple wherein the Theoretic faculty, in its turn, does deepest homage. Thus sympathetic in their desires, harmoniously diverse in their operation, each working for the other with what the other needs not, all things external to man are by one or other turned to good.

From Walter Pater's Studies in the History of the Renaissance:

To regard all things and principles of things as inconstant modes or fashions has more and more become the tendency of modern thought. (...)

Or if we begin with the inward world of thought and feeling, the whirlpool is still more rapid, the flame more eager and devouring. There it is no longer the gradual darkening of the eye, the gradual fading of colour from the wall movements of the shore-side, where the water flows down indeed, though in 
apparent rest - but the race of the midstream, a drift of momentary acts of sight and passion and thought. (...)

To burn always with this hard, gem-like flame, to maintain this ecstasy, is success in life. In a sense it might even be said that our failure is to form habits: for, after all, habit is relative to a stereotyped world, and meantime it is only the roughness of the eye that makes two persons, things, situations, seem alike. While all melts under our feet, we may well grasp at any exquisite passion, or any contribution to knowledge that seems by a lifted horizon to set the spirit free for a moment, or any stirring of the sense, strange dyes, strange colours, and curious odours, or work of the artist's hands, or the face of one's friend. Not to discriminate every moment some passionate attitude in those about us, and in the very brilliancy of their gifts some tragic dividing on their ways, is, on this short day of frost and sun, to sleep before evening. With this sense of the splendour of our experience and of its awful brevity, gathering all we are into one desperate effort to see and touch, we shall hardly have time to make theories about the things we see and touch. What we have to do is to be for ever curiously testing new opinions and courting new impressions, never acquiescing in a facile orthodoxy, of Comte, or of Hegel, or of our own. Philosophical theories or ideas, as points of view, instruments of criticism, may help us to gather up what might otherwise pass unregarded by us. "Philosophy is the microscope of thought". The theory or idea or system which requires of us the sacrifice of any part of this experience, in consideration of some interest into which we cannot enter, or some abstract theory we have not identified with ourselves, or of what is only conventional, has no real claim upon us.

The above fragments representing Victorian criticism, selected from Matthew Arnold's The Study of Poetry, John Ruskin's Modern Painters, and Walter Pater's Studies in the History of the Renaissance, do not show any similarities in matters of ideas expressed in them. Moreover, the three critics represent different literary and critical trends, and, in matters of their critical concern, Ruskin's and Pater's main focus is on art, in general, and, in particular, on painting, and not on literature, as it is poetry for Arnold.

The reason behind the selection is that all three fragments contain - apart from critical ideas on art and artist (Ruskin and Pater), and on poetry and the poet (Arnold) - clear references to criticism, indicating the condition and diversity of critical thought in the Victorian period, and, first and foremost, revealing the changes taking place in that period regarding the status and purpose of criticism.

The condition of literary criticism in the Victorian age, as revealed in the fragment from The Study of Poetry, expresses a typology, a variety of critical approaches to poetry, Arnold speaking about three types of criticism, or "estimate": "historic estimate", "personal estimate", and the "real estimate". The "real estimate" is Arnold's own humanistic and moral criticism, "the only true one" in his opinion, since its aim is to unveil "a clearer, deeper sense of the best in poetry, and of the strength and joy to be drawn from it", and assist the reader in understanding what is the best in poetry. The true criticism should be objective, whereas the other two types of criticism, "historic" and "personal", are both wrong, both "fallacious", the main problem in both cases being the subjective response to poetry on either historical or personal grounds. Both 
historic and personal types of criticism give an untrue understanding of poetry, because they both are subjective, using "a language of quite exaggerated praise in criticising" poetry and over-rating its value. Subjectivity results from the consideration of a poem in relation to some historical or personal affinities and circumstances, which the true criticism must avoid.

Evidence on the status of criticism in the Victorian age is also given in the fragment from Modern Painters, in which John Ruskin distinguishes between the "Imaginative faculty" and "Theoretic faculty" and thus considers criticism to be independent from artistic practice. The imaginative faculty belongs to the artist, and the imaginative artist, the only true one, unlike the unimaginative artist (who tends only towards perfection), embraces perfection and imperfection, beauty and ugliness, and defies all laws and limits. The theoretic faculty belongs to the critic, and, as discussed in relation to the theoretic faculty, imagination, the faculty of the artist, "takes hold of the very imperfections which the Theoretic rejects". Criticism, then, according to Ruskin, although interdependent and placed in "noble sympathy and unity" with the imaginative faculty, both agreeing in "that they reject nothing, and are thankful for all", is different in its concern and mode of operation from the imaginative faculty and as such, should be considered as an independent from artistic practice discipline: although "sympathetic in their desires", the theoretic and imaginative faculties are "harmoniously diverse in their operation, each working for the other with what the other needs not, all things external to man are by one or other turned to good".

Walter Pater, in the fragment from Studies in the History of the Renaissance, more precisely from the Conclusion to this book, promotes the freedom of artistic creation and reception and rejects the prescriptive and normative features of theory and criticism. Pater points to the modern world growing accustomed to different and continuously changing manners and methods which might intervene between art and its perception. In their place, Pater advocates impressionistic criticism, according to which the artistic perception is a private experience, a personal understanding, consisting in a myriad of impressions emerging from the individual "inward world of thought and feeling". The experience of perception, involving observation and analysis, of the artistic object is thus reduced to a group of impressions, these individual "momentary acts of sight and passion and thought". It is a human mistake to establish and follow rules and convention or, as Pater puts it, "our failure is to form habits". Instead, one should let himself be taken by that movement of impressions and to maintain the spirit connected to the intense but fleeting chain of impressions represents "what is real in our life" and what "is success in life". Life itself is fleeting, and, instead of pursuing some ultimate truths and theories, one should follow impressions, and let the spirit be free for at least a moment from any constraints of traditional theories, so that,

while all melts under our feet, we may well grasp at any exquisite passion, or any contribution to knowledge that seems by a lifted horizon to set the spirit free for 
a moment, or any stirring of the senses, strange dyes, strange colours, and curious odours, or work of the artist's hands, or the face of one's friend.

This moment of artistic comprehension has been equalled to the moment of "epiphany" in Marius the Epicurean and later in the works of modernists, in particular in Joyce's fiction. In the experience of artistic reception, insists Pater, one should be free in his/her response to the artistic object, and never acquiesce in any theory or convention, such as that of Comte or of Hegel, or even the impressionistic one of Pater himself. Instead, "what we have to do is to be for ever curiously testing new opinions and courting new impressions". Criticism, then, with its "instruments", which are "philosophical theories or ideas, as points of view", is needed to assist the viewer in artistic reception by helping "us to gather up what might otherwise pass unregarded by us". And, concludes Pater, rejecting the normative and prescriptive types of critical analysis, criticism provides insight into philosophy, or unknown to the receiver theories, or conventional opinions on the object, without determining or influencing in any way the act of artistic creation and the receiver's reception of the artistic object, that is, having "no real claim upon us".

These fragments contain some minor elements of metacriticism, and it is worth mentioning that criticism of criticism in its both diachronic and synchronic perspectives emerges as a serious concern in numerous Victorian works, such as Essays, Critical and Miscellaneous (1861) by T. B. Macaulay, Cobwebs of Criticism (1883) by Hall Caine, Comparative Literature (1886) by H. M. Posnett, Literary Criticism for Students (1893) by E. T. McLaughlin, and later at the dawn of a new century, George Saintsbury's A History of Criticism and Literary Taste in Europe (1900-1904) and Loci Critici (1903).

Metacriticism in its incipient stage also includes An Introduction to the Methods and Materials of Literary Criticism (1899) by Charles Mills Gayley and Fred Newton Scott who approach criticism both synchronically and diachronically. Gayley's and Scott's book is particularly interesting as it gives the direct testimony of the condition of literary criticism from within its own cultural and literary context. Thus, after presenting the kinds of criticism in general as being historical, scientific, literary, and philosophical (depending on its subject matter and method), Gayley and Scott distinguish a number of types of literary criticism, which are judicial, inductive, personal or subjective, impersonal or objective, analytic, synthetic, positive, negative, scientific, philosophic, ethical, aesthetic, and so on, as to finally conclude that "possibly not comprehensive and strictly logical classification has yet been made" (Gayley, 1999, p. 6).

\section{Concluding Reflections}

The Victorian age was a period of great increase in literary and critical productivity following the Romantic break with linear development of literature dominated by classical principles and the Romantic claim of freedom of artistic expression and revival of literary experimentation and originality. In the Victorian age, the co-existence of different artistic and literary trends during one period represents the co-existence of tradition and innovation, socially 
concerned art and art per se, namely realism, which replaced the old mimesis, and its opposing impressionism, symbolism, and aestheticism.

Amid the literary and philosophical diversity, the nineteenth century saw the diversification and separation of literary theory and criticism from the literary process and the constraints of artistic and literary trends and movements, which would result in the contemporary scientific and methodological evaluation of literature.

This separation caused the diminution of the previous characteristics of criticism as subjective, defensive, prescriptive, normative and dependent on the literary background to which it belongs. Thus, in The Study of Poetry, Arnold rejects subjectivity in criticism and points to a critical typology in Victorian period; in Modern Painters, Ruskin rejects the dependence of criticism on period and literary movement; and, in Studies in the History of the Renaissance, Pater rejects the prescriptive and normative features of criticism.

This separation between criticism and literary movements is an outcome of the development by criticism of its own types - humanistic, historical, sociological, moral, biographical, aesthetic, impressionistic, and others - most of which being different from the literary ones, although the Romantic theory is still highly influential.

The diversification of the critical systems in the second half of the nineteenth century is the result of the massive presence of different critical voices, many of which were highly influential.

But the main reason for the separation of criticism from literature in the Victorian age and the establishment of a critical typology is the impressive amount of newly emerging philosophical, social and scientific theories.

Taking science as a model for literary research made possible the consideration of criticism as being allied to fields other than art and literature, from which the critic would borrow arguments and methodological principles applicable in literary evaluation. Once proved functional and productive, these arguments and methods diversified the critical perspectives (individual psychology, genesis of the work, rules of the work, the relationship between literature and reality, etc.) and established a typology of the critical act (psychological criticism, historical criticism, sociological criticism, and so on).

Whatever its types and in spite of its diversity, an important amount of the Victorian critical discourse rejects Romantic and subjective criticism and tends to become objective, positivist, scientific, and socially concerned, which is in the spirit of Taine, Comte, Zola, Arnold, and others.

Others, like Pater and Wilde, proclaim the autonomy of art and disconsider the creative personality of the author or the social and moral usefulness of art.

However, there is also a revived interest in the public as the element of reception, and inheriting from Romanticism the theory of authorship, a part of the nineteenth century critical thought kept the interest in the personality of the writer alive. 
The diversification and organization of criticism as a typology in Victorian Britain, like on the Continent, are complex and difficult to follow, yet, although impressive in their diversity, the major types of criticism might be grouped into certain distinct sets.

In general, apart from the Romantic theory which remains influential after Romanticism seized to exist as a regular movement from about 1830 onwards, paralleling the shift of the literary concern from subjectivity to either society or the literary work in itself, and conditioned by the growing influence of history and science over the thinking and practical activities, literary theory moved from the expressive theory of authorship to (1) social theories of literature and (2) objective theory of art.

First, as a common point, the socially and morally concerned theories are based on the idea that literature is the expression of society and that the author is an intermediary factor between society and literature. This group includes the theories of Taine, Comte, Zola, Arnold, and the entire spectrum of the nineteenth century social, sociological, positivist, humanistic and moral analyses of literature, which are also referred to as the "socio-culturalhistorical" approach to literature. Where for Matthew Arnold criticism would consider the effects of literature on society, for Taine, Comte and the entire sociological criticism of the period the main interest is in society as the cause of literature and literature as the product of society.

Second, contrary to these critical theories, but also like them diminishing the status and the role of the author, is, according to Abrams, the objective theory of art. It comprises some Romantic views, impressionistic critical method, symbolist attitudes, and above all aestheticism. The objective theory was embraced by, among others, Gautier, Pater, Wilde, Poe, Ruskin, the symbolists, the Pre-Raphaelites, and by other representatives of the nineteenth century avant-garde who supported the view that art is autonomous and the idea of "art for its own sake".

Also, the newly emerging critical systems in the second half of the nineteenth century reveal objectivity and subjectivity as the two contrary aspects of the critical reception of the literary work. The positivist philosophy, in particular, prompted scientism and stimulated the attempt to scientize the criticism, where the scientific method would provide the critical act with an objective model of study and a solid theoretical substratum. On the contrary, the subjective and idealist criticism maintains the belief that the critical act is the expression of the individual affective response to the work. The passionate and partial point of view was supported first of all by writers, as by Baudelaire, but also by critics, especially Sainte-Beuve, whose concerns include the moral portrait of the writer and the psychological implications of the literary text.

The separation of criticism from literature and its diversification into types and trends make Victorian age a period of transition from old, traditional, scholarly, humanistic and moral criticism to a new one which, at the beginning of the twentieth century, becomes more scientific and methodological through the 
effort of a new generation of academic critics who would replace the views of the former writer-critics by the focus on text in itself and poetic language, and through "close reading" and "practical criticism", make the study of literature a systematic approach.

With the rise of textuality, the focus on reader, and the new historical and cultural views, the first decades of the twentieth century extend further the acquiring of independence by criticism from literature and continue largely the main trends in critical thinking of the last part of the previous century, but certain social movements (Marxism, feminism) and especially the modernist literature, the new trends in visual arts, the new developments in philosophy (phenomenology), psychology (Freud), and linguistics (Saussure) cause the development of many and different kinds of theoretical criticism having new concerns and methodologies and making twentieth century indeed an age of criticism.

\title{
REFERENCES
}

Abrams, M. H. (1953). The Mirror and the Lamp: Romantic Theory and the Critical Tradition. Oxford: Oxford University Press.

Castle, G. (2007). The Blackwell Guide to Literary Theory. Oxford: Blackwell Publishing.

Culler, J. (2009). Literary Theory. New York: Sterling Publishing Co., Inc.

Daiches, D. (1981). Critical Approaches to Literature. London: Longman.

Day, G. (2008). Literary Criticism: A New History. Edinburgh: Edinburgh University Press.

Fokkema, D., \& Ibsch, E. (1995). Theories of Literature in the Twentieth Century: Structuralism, Marxism, Aesthetics of Reception, Semiotics. New York: St Martin's Press.

Frye, N. (1990). Anatomy of Criticism: Four Essays. London: Penguin Books.

Gayley, C. M., \& Scott, F. N. (1999). An Introduction to the Methods and Materials of Literary Criticism. Boston: The Athenaeum Press.

Jauss, H. R. (1982). Toward an Aesthetic of Reception. Minneapolis: University of Minnesota Press.

Lodge, D. (1971). The Novelist at the Crossroads and Other Essays on Fiction and Criticism. Ithaca: Cornell University Press.

\section{VICTORIAN CRITICS AND METACRITICS: ARNOLD, PATER, RUSKIN AND THE INDEPENDENCE OF LITERARY CRITICISM}

\begin{abstract}
The Victorians provide the last major step in the advancement of English critical theory before its twentieth century establishment as a scientific and methodological discourse. It is also true to assume that Victorian criticism represents the transition to or culminates in modern literary theory and criticism. In the nineteenth century, the co-existence of different artistic and literary trends during one period leads to the
\end{abstract}


separation of criticism from literary process. The separation of criticism from literary practice is also a result of the diversity of literary forms. But primarily the independence of criticism from literature is acquired by creative and critical writing confronting and falling under the influence of diversity and complexity of philosophical thought, social theories and scientific advances, where critics attempt to assimilate science to literary criticism. The route of criticism towards independence from literature means its own diversification and organization as a typology: although it is almost impossible to categorize Victorian criticism, it is Romantic theory still being influential, to which biographical, sociological, historical, positivist, realistic, naturalistic, impressionistic, aesthetic, moral, humanistic, and other types of criticism are added. The diversification of the critical systems in the Victorian Age is the result of the massive presence of different critical voices belonging to both professional critics, like John Ruskin, and writer-critics, like Walter Pater, Matthew Arnold and Henry James. Among others, they are critics focusing on art and/or literature as well as metacritics providing critical commentary on criticism. To reveal the significance of their critical status and disclose their ideas showing the condition of Victorian criticism represent the aim of the present paper.

Keywords: Victorian Age, Approaches to Literature, Literary Criticism, Literary Theory, Literary History, Metacriticism, Critic, Metacritic, Writer-Critic. 